Figure S1. Correlation between modelled GPP output and Landsat-derived NDVI

\section{Burnt area}
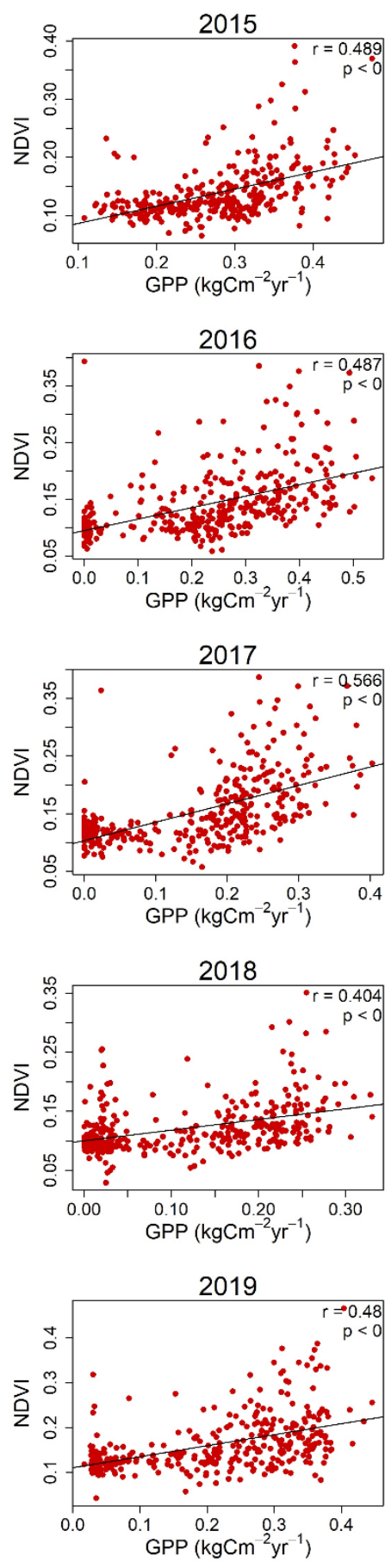

Unburnt area
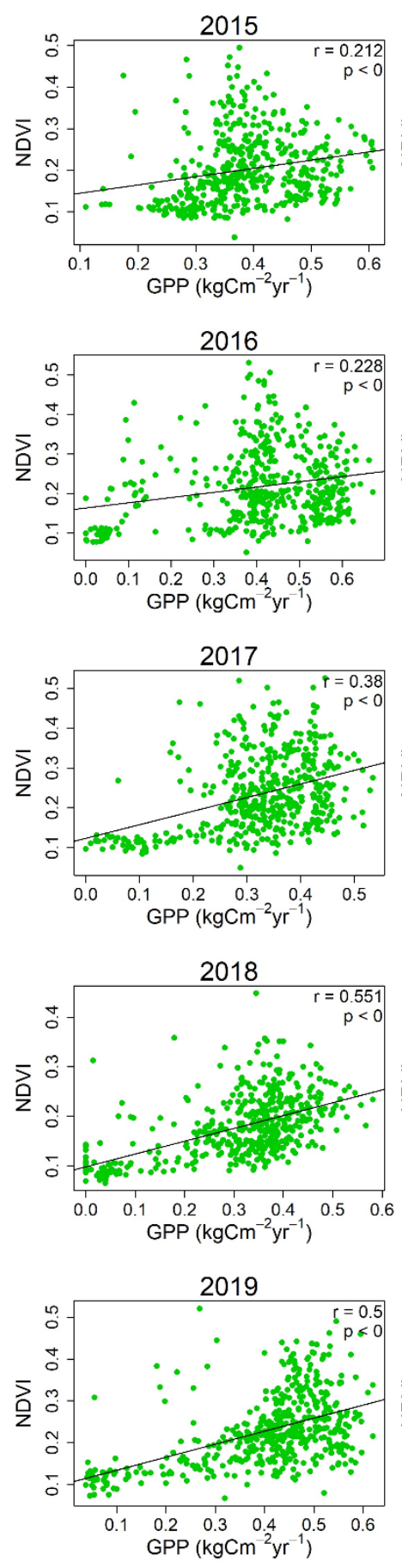

Whole area
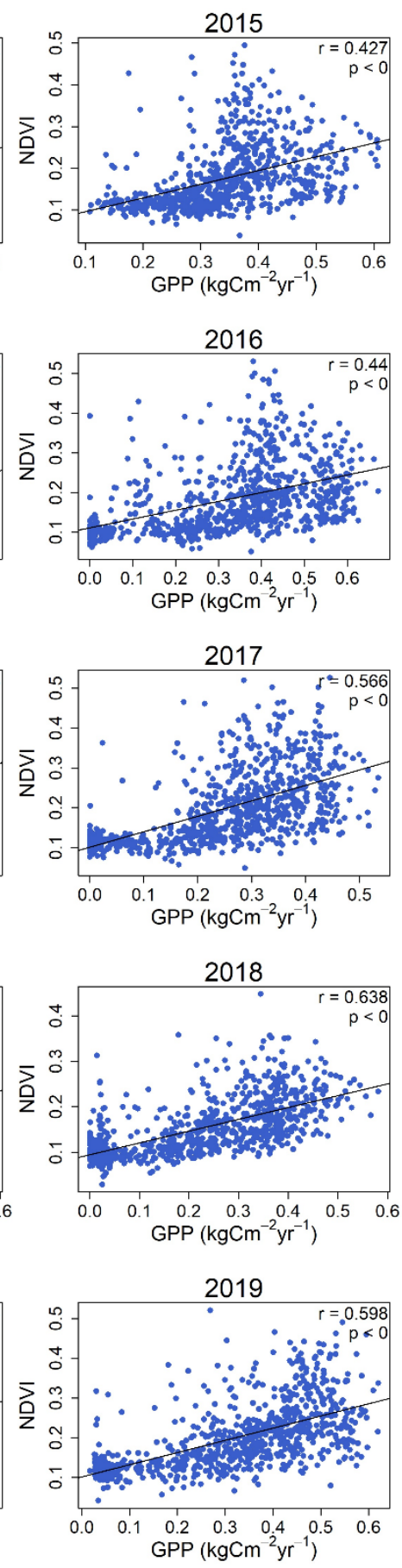